\title{
Regime SWitching Stochastic Volatility: OUTPUT GROWTH BEHAVIOUR
}

M. Kenan TERZIOOĞLU

\begin{abstract}
The output volatility can cause the recession in the economy by random shocks. Growth volatility, output variability, fluctuation in output, and business cycle volatility are used as the output uncertainty in the literature. Regime switching and the stochastic volatility is combined within this paper to explain the behaviour of output growth and its volatility. Moreover, this study pointed out the sign and direction of the relation between output growth and its uncertainty in Turkey as a developing country. In the scope of the study, a single economic variable is preferred as a reference series and, although GDP is the "reference" series that determines the situation of economic activity, monthly industrial production index series, high frequency data, is used between 1987: 01-2017: 04 monthly periods to reveal better the structure of the volatility instead of quarterly basis GDP.
\end{abstract}

Key Words: Stochastic volatility, Regime switching model, Output growth.

Jel Codes: C22, C50.

\section{ReJim DeĞiş̧im Stokastí OYNAKLIK MOdeli̇: ÇıKTI BÜYÜKLÜĞÜ DAVRANIŞI}

$\ddot{O} z e t$

Çıktı oynaklı̆̆l, rasgele şoklarla ekonomide daralma meydana getirebilmektedir. Büyüme oynakliğl, çıktı değişkenliği, çıktıdaki dalgalanma ve iş çevrimi oynaklığı terimleri çıktı belirsizliğine özdeş olarak kullanılmaktadır. Stokastik oynaklık modeli ile Markov rejim geçişleri birleștirilerek çıkt büyüklüğ̈̈ ve oynaklığının davranış yapısının ortaya çıkarılması amaçlanmaktadır. Ek olarak, bu çalışma, çıktı büyüklüğü ve belirsizliği arasındaki ilişkinin yönünü ve işaretini gelişmekte olan ülkeler sınıfinda olan Türkiye için incelemektedir. Çalışma kapsamında, referans dizi olarak tek bir değişken ele alınmakta ve GSYIH ekonomik faaliyetin durumunu belirleyen "referans" serisi olmasına răgmen, oynaklık yapısını daha iyi ortaya çıkarmak için 1987:01-2017:04 dönemlerini kapsayan aylık sanayi üretim endeksi çeyrek bazda yayınlanan GSYIH yerine kullanılmaktadır.

Anahtar Kelimeler: Stokastik oynaklık, Rejim geçiş modelleri, Çıktı büyüklüğü.

Jel Siniflandirilmast: C22, C50.

\footnotetext{
${ }^{1}$ Dr. Öğr. Üyesi, Trakya Üniversitesi, İ̈BF, kenanterzioglu@trakya.edu.tr
} 


\section{INTRODUCTION}

Until the 1980s, business cycle theories focused on the output deviations while growth theories focused on the growth determinants. After the 1980s, with the changes in economic structure, it became important to deal with these two theories and develop different model structures that reveal the relationship between business cycle and output growth fluctuations. Business cycle theory is important in order to understand the causes of economic fluctuations in developed and developing countries. Lucas (1983) defines business cycles as employment, output, and recurrent movements in the composition of output in relation to simultaneous movements of output on prices and other variables. Although the unforeseeable changes in the money supply cannot solely cause business cycles, the transition from financial business cycles to real business cycles has begun. Monetary policy mistakes, nominal shocks, and lack of information are underlined as the causes of business cycles. Since business cycles emerge because of industrialization and proliferation of monetary economies, they are associated more with industrial and trade sectors in deliberation within the economic structure.

Traditional business cycle model indicates that there is no relationship between output fluctuations and growth (Friedman, 1968). In business cycle model, it is assumed that the output gets further away from natural rate as a result of misperception of price levels. Therefore, the long-term output growth is independent from information asymmetry. Changes in rate of output growth are caused by real factors. Lucas (1988) showed that, independent of output fluctuations, there is no transition between growth and business cycles in the long run.

Schumpeter (1939) emphasized the existence of a positive relationship between output volatility and growth rates since output fluctuations during periods of recession lead to research and development (R\&D) spending. Black (1987) argued that, contrary to the traditional business cycle theory, there is a positive relationship between output volatility and average growth. The investments in high-risk technologies can be sustained only if the expected returns of these investments are large enough to compensate for the additional risk. Sandmo (1970) and Mirman (1971) claimed that since more income variability (uncertainty) leads to higher rate of economic growth, because of precautionary reasons, according to the neoclassical growth theory, due to the higher rate of savings. Blackburn (1999) showed that business cycle volatility increases long-term growth of the economy. Abel (1983) and Caballero and Hammour (1994) showed the existence of a positive relationship between growth and volatility.

Keynes (1936) argued that the perception of investment projects as more risky, when there are fluctuations in the economy, reduces investment-production demand. In this context, entrepreneurs take the fluctuations in economic activity into consideration when calculating the return on their investments. Bernanke (1983) and Pindyck (1991) pointed out that the negative relationship between output fluctuation and growth is caused by the lack of return on investment at firm level. Aghion and Howitt (2006) expressed the existence of a negative relationship between output growth and volatility.

Blackburn and Pelloni (2004) showed that the correlation between output growth and volatility is a function of the types of shocks sustained in the economic structure. Additionally, output growth can also have direct /indirect effect on output uncertainty. The increase of output growth can lead to high inflation (short-term Phillips curve) and inflation uncertainty (Friedman, 1977). The increase in inflation uncertainty reduces the real uncertainty (Taylor, 1979) and brings out a negative relationship between output growth and output uncertainty. From another point of view, the decline in output growth in response to monetary policy shocks creates more uncertainty in future prices and causes a decrease in output uncertainty as a reaction. 


\section{ECONOMETRIC METHODOLOGY}

A correct specification of output volatility (uncertainty) is important to make efficient econometric inferences. The stochastic volatility (SV) models that involve observable data and unobservable conditional variance give better in sample fit and do better out-of-sample forecast than ARCH-type models (Kim et al., 1998; Yu,2002) In periods of volatility jumps, stochastic volatility models provide superior forecasts (Geweke, 2005).

\section{I.I. Stochastic Volatility}

While conditional variance is modelled as an observable function under generalized autoregressive conditional heteroscedasticity $(\mathrm{GARCH})$ models, it is modelled as an unobservable variable in SV models. The SV models, which assumes that the unknown volatility changes in a stochastic manner over time, has better forecasting performance than the GARCH models do. Variance is used logarithmically for the positive definiteness of conditional variance in the SV model. Variance is taken as an unobservable component and is modelled as a state-space model. In stochastic volatility, it is assumed that while time series, in continuous time, follows a geometric Brownian motion; the time series is martingale and its logarithmic variance, in discrete time, follows an autoregressive process. While log-variance is $h_{t}$, unconditional mean is $\mu$, autoregressive term is $\phi$, and standard deviation is $\sigma$, then $r_{t}$

$r_{t}=\exp \left(\frac{h_{t}}{2}\right) u_{t}$

$h_{t}-\mu=\phi\left(h_{t-1}-\mu\right)+\sigma \varepsilon_{t}$

can ben modelled as above (Vo,2009). $u_{t}$ and $\varepsilon_{t}$ are i.i.d and their covariance is zero. Stochastic volatility model, composed of observation equation and state equation, can be expressed as a linear model (state-space). The error term of the observation equation does not show a normal distribution. In models such as SV modelling that do not show normal distribution, the Monte-Carlo importance sampling can be used. While $\ln L_{G}(Y \mid \Psi)$ is log-likelihood function of the model that is approaching normal distribution; $p_{T}(\varepsilon \mid \Psi)$ is density function of observation equation error term and $p_{G}(\varepsilon \mid \Psi)$ is normal density function of the approximate model error term the state space model with error term having non-normal distribution defined as

$\ln L(Y \mid \Psi)=\ln L_{G}(Y \mid \Psi)+\ln E_{G}\left[\frac{p_{T}(\varepsilon \mid \Psi)}{p_{G}(\varepsilon \mid \Psi)}\right]$

and the unbiased estimation of the likelihood function of it can be shown as

$\ln \widehat{L}(\Psi)=\ln L_{G}(Y \mid \Psi)+\operatorname{In} \bar{w}+\frac{s_{w}^{2}}{2 T \bar{w}^{2}}$

where $\bar{w}$ and $s_{w}^{2}$ values are obtained with the algorithm (Durbin ve Kopman,1997). $\phi$ should be less than one to ensure the stationary condition. There is a high persistence in the conditional variance in SV models.

\section{I.II. Stochastic Volatility with Markov Regime Switching}

The Markov switching model has been effective in modelling business cycle, interest rates, exchange rates, etc. Based on different regime structures, MS models provide information about the effects of data on fluctuations, turning points of fluctuations, and the duration of fluctuation intervals. The structure that appeared at a random time leaves its place to a new structure with the switch in regimes. That is why the switches between regimes, which occurred at a random time, are completely independent. When the series is assumed to have a turning point on its independent average in period $t_{1}$, under the information that $\varepsilon_{t} \sim$ i. i. d N $\left(0, \sigma^{2}\right)$ and $\left|\Phi_{1}\right|<1$, the model structure can be written for observation values prior to $t_{1}$ 
$h_{t}-\mu_{1}=\Phi_{1}\left(h_{t-1}-\mu_{1}\right)+\varepsilon_{t}, t<t_{1}$

and for observation values after $t_{1}$,

$h_{t}-\mu_{2}=\Phi_{2}\left(h_{t-1}-\mu_{2}\right)+\varepsilon_{t}, t \geq t_{1}$

$\Phi_{1}$ and $\Phi_{2}$ coefficients explain the behavior of the series before and after $t_{1}$ moment and ensure a better observation of the change that will take place. Additionally, if the cause of the change that took place in $\mu_{1}$ and $\mu_{2}$ is unknown than series cannot be foreseen. Since economic fluctuations involve more than one turning points and shifts, in period $t$, a defined regime variable $s_{t}$ can take different values.

$h_{t}-\mu_{s_{t}}=\Phi\left(h_{t-1}-\mu_{s_{t}-1}\right)+\varepsilon_{t}$

is obtained for $s_{t}=1$ and $s_{t}=2$ where the mean values are $\mu_{1}$ and $\mu_{2}$, respectively. There is a regime in MS-AR model to reflect each parameter that exists in the AR process. The notion of Markov Chain constitutes the foundation of MS models. While the probability of a first-degree Markov chain is

$P\left(s_{t}, s_{t-1}, s_{t-1}, \ldots, s_{0}\right)=P\left(s_{0}\right) P\left(s_{1} \mid s_{2}\right) \ldots P\left(s_{1} \mid s_{t-1}\right)$

and a second-degree Markov chain is obtained as

$P\left(s_{t}, s_{t-1}, s_{t-1}, \ldots, s_{0}\right)=P\left(s_{0}\right) P\left(s_{1} \mid s_{0}\right) \ldots P\left(s_{t} \mid s_{t-1}, s_{t-2}\right)$

Here, the regime elements of $\mathrm{P}$ matrix are expressed respectively as $p_{11}=\left[s_{t}=1 \mid s_{t-1}=\right.$ $1]=p$ that gives the probability of transition from first regime to first regime, $p_{12}=$ $\left[s_{t}=2 \mid s_{t-1}=1\right]=1-p$ that gives the probability of switching from first regime to second regime, $p_{21}=\left[s_{t}=1 \mid s_{t-1}=2\right]=q$ that gives the probability of switching from second regime to first regime and $p_{22}=\left[s_{t}=2 \mid s_{t-1}=2\right]=1-q$ that gives the probability of switching from second regime to second regime (Hamilton, 1994).

Regime switching stochastic volatility assists to conquer structural changes of the volatility process and give information when there is a jump in volatility. When unconditional mean of return $m, \mu_{s_{t}}$ is the stationary mean of $h_{t}, \gamma$ which is constrained to be positive is the sensitivity of $\mu_{s_{t}}$ to the latent state, the MSSV model

$r_{t}-m=\beta\left(r_{t-1}-m\right)+\exp \left(\frac{h_{t}}{2}\right) u_{t} u_{t} \sim \operatorname{IID}(0,1)$

$h_{t}-\mu_{s_{t}}=\phi\left(h_{t-1}-\mu_{s_{t-1}}\right)+\sigma \varepsilon_{t} \quad \varepsilon_{t} \sim \operatorname{IID}(0,1)$

$\mu_{s_{t}}=\mu+\gamma s_{t} \gamma>0 s_{t}=\{0,1\}$

$\operatorname{prob}\left(s_{t}=j \mid s_{t-1}=i\right)=p_{i j}$

can be written as above. $\mu_{s_{t}}$ follows a two-state ergodic discrete first-order Markov process. $\mu_{t}$ and $\varepsilon_{t}$ are assumed to be independent $(\mathrm{Vo}, 2009)$. 


\section{THE BEHAVIOUR OF THE OUTPUT GROWTH}

The industrial production index (IPI), also called industrial output index or industrial volume index, is a business cycle indicator that measures monthly changes in the price-adjusted output of industry. Industrial production index for 1987:01-2017:04 monthly periods are obtained from the Electronic Data Distribution System, Central Bank of the Republic of Turkey. The dynamic structure can be examined by observing output growth. Figure 1. shows the tendency of the output growth rate with respect to time. Ljung-Box portmanteau test at 12 and 24 lags, respectively 81.94 and 183.00, suggest that both $r_{t}$ and $\varepsilon_{t}$ are highly autocorrelated and it is found that there is a strong ARCH effect $\left(T * R^{2}=52.82\right)$. Because output growth series exhibits autocorrelation and heteroscedasticity, stochastic volatility can be used to explain the behaviour of the output growth.

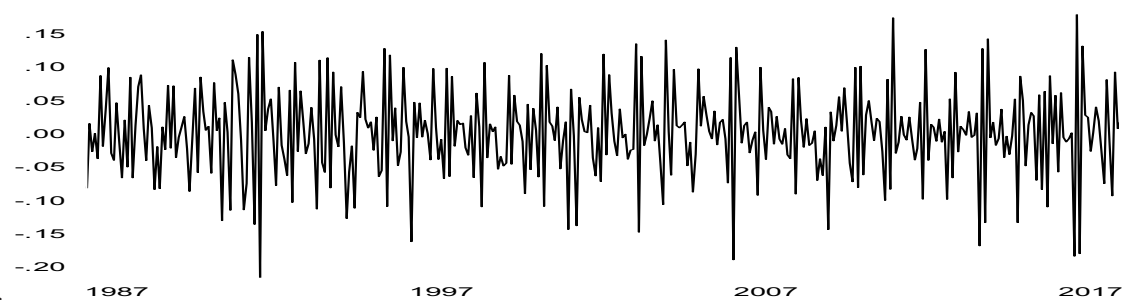

Figure 1. Tendency of Output Growth Rate by Time

Growth measures expressed as percentage changes are obtained by taking the logarithmic firstorder-differences. Augmented Dickey-Fuller (ADF), Phillips-Perron (PP), Kwiatkowski-PhillipsSchmidt-Shin (KPSS) tests are applied to the output growth in Table 1. for set out the stationarity. It is determined that the output growth is stationary at $\% 5$ significance level.

Table 1. Unit Root Test Results

\begin{tabular}{lc}
\hline Unit Root Test & $\begin{array}{c}\text { Statistical Values } \\
\text { (Constant and Trend) }\end{array}$ \\
\hline ADF & $-6.4081^{* *}$ \\
PP & $-33.5237^{* *}$ \\
KPSS & 0.0215 \\
\hline$* 0.01, * * 0.05$ and ${ }^{* * *} 0.10$ show levels of importance.
\end{tabular}

The model structure used in this article is given as follows:

$$
\begin{aligned}
& r_{t}-m=\beta\left(r_{t-1}-m\right)+\exp \left(\frac{h_{t}}{2}\right) u_{t} \\
& h_{t}-\mu_{s_{t}}=\phi\left(h_{t-1}-\mu_{s_{t-1}}\right)+\delta_{1} r_{t-1}+\sigma \varepsilon_{t}
\end{aligned}
$$

If $\gamma=0$, the model turns SV model. In order to catch the growth dynamics, mean equation for output is defined as an auto-regressive model. The appropriate lag used in the model were determined using the Akaike information criteria (AIC). Parameter estimations and test statistics of the SV and MSSV models' mean and variance equation are shown in Table 2. To allow past output growth affect the output uncertainty, the variance equation is consist of output growth with one lag. Since $\phi$, used to find the stability of shocks is statistically meaningful and smaller than one, it is 
determined that $h_{t}$ is stationary. It is found that a one-period lag in the output growth, which is included in the variance equation, is statistically meaningful and has a positive effect.

Table 2. Parameter Estimations of SV Model and MSSV Model

\begin{tabular}{|c|c|c|c|c|}
\hline Parametre & $\widehat{\boldsymbol{R}}$ & SV Model & $\widehat{\boldsymbol{R}}$ & MSSV Model \\
\hline $\mathrm{m}$ & 1.00 & $0.48^{*}$ & 1.09 & $3.25^{*}$ \\
\hline$\beta$ & 1.00 & $0.27 * *$ & 1.00 & $0.21 * *$ \\
\hline$\delta_{1}$ & 1.10 & $0.11 *$ & 0.99 & 0.10 \\
\hline$\mu$ & 1.00 & $4.36^{* *}$ & - & - \\
\hline$\mu_{1}$ & - & - & 1.00 & $4.32 * *$ \\
\hline$\mu_{2}$ & - & - & 1.19 & $7.52 * *$ \\
\hline$\sigma$ & 1.07 & $0.30^{*}$ & 1.09 & $1.02 *$ \\
\hline$\phi$ & 1.05 & $0.95 * *$ & 1.00 & $0.64 * *$ \\
\hline$p_{11}$ & - & - & 0.99 & $0.99 * *$ \\
\hline$p_{22}$ & - & - & 1.00 & $0.68 * *$ \\
\hline \multicolumn{5}{|c|}{ Forecast Performance } \\
\hline & MAE & & & Theil -U \\
\hline \multicolumn{5}{|l|}{ In-sample } \\
\hline SV & 0.09 & & & 2.72 \\
\hline MSSV & 0.11 & & & 7.58 \\
\hline \multicolumn{5}{|l|}{ Out-sample } \\
\hline SV & 0.08 & & & 0.92 \\
\hline MSSV & 0.06 & & & 0.48 \\
\hline
\end{tabular}

In this paper, output growth $\left(r_{t}\right)$ is modelled with an $\mathrm{AR}(1)$ process and a stochastic volatility. $\mu_{t}$ and $\varepsilon_{t}$ are assumed to be normal. Moreover, the prior distributions of $m$ and $\mu$ are assumed normal. Bayesian MCMC method with Gibbs sampling algorithm is used in estimation of MSSV model. $\beta$ and $\phi$ are constrained in order for $r_{t}$ and $h_{t}$ to be stationary. Gelmen and Rubin (1992) approach shows that potential scale factor $\hat{R}$ is close to one for every parameter means that the results are not sensitive to the initial value. It is observed that all parameters are significantly at $\% 5$ and $\% 10$ significance level. $\varphi$ is found close to unity means in SV model that a shock to volatility is highly persistent. While all parameter estimates are found significantly at $\% 5$ and $\% 10$ significance level in MSSV model, $\Phi$ is significantly reduced. To evaluate the forecasting performance of a model, realized volatility is obtained by $\sigma_{t}^{2}=\sum_{i=1}^{n_{t}} r_{i}^{2}$ where $r_{i}$ is the daily return on day i and $n_{t}$ is the number of trading days in a montht. The root mean square error (RMSE), the mean absolute error (MAE), and the Theil-U statistic are used to evaluate the forecasting performance. SV model shows the best performance under two of them in sample. However, the MSSV model shows best performance, the lower the metrics, under all of them in the out of sample.

Table 3. Granger Causality between Output Uncertainty and Output Growth

\begin{tabular}{lllllr}
\hline$r_{t} \nRightarrow h_{t}$ & 4. lag & $4.38^{* *}(+)$ & $h_{t} \nRightarrow r_{t}$ & 4. lag length & $0.43^{*}(+)$ \\
& 8. lag & $2.25^{*}(+)$ & & 8. lag length & $0.48^{*}(+)$ \\
& 12. lag & $2.37^{* *}(+)$ & & 12. lag length & $0.67^{*}(+)$ \\
\hline${ }^{*} 0.01, * * 0.05$ and ${ }^{* * *} 0.10$ show levels of importance.
\end{tabular}

Table 3 shows the results of $\mathrm{F}$ statistics for the Granger causality analysis between output uncertainty and output growth. $r_{t} \nRightarrow h_{t}$ shows the null hypothesis which means that $r_{t}$ is not the Granger causality of $h_{t}$. The null hypothesis indicating that the output growth is not the causality of output uncertainty is rejected at the $5 \%$ significance level; whereas, the null hypothesis indicating that the output uncertainty is not the causality of output growth is rejected at the $10 \%$ significance level. Since the results are sensitive to the lag lengths, the appropriate lags are assumed 4, 8 and 12 . It is found that there is bi-directional Granger causality between the output uncertainty and output growth. It is observed that the total sum of the delayed coefficients is positive $\left(r_{t} \nRightarrow h_{t}\right)$ and positive $\left(h_{t} \nRightarrow r_{t}\right)$. 


\section{CONCLUSION}

After the regime switching stochastic volatility model is estimated by the Bayesian Markov chain Monte-Carlo method with the Gibbs sampling algorithm, the performances of the stochastic volatility and regime switching stochastic volatility model are evaluated by comparing the forecasting powers. It can be said that changes in regime might create an artificially high persistence in volatility because the persistence parameter is found smaller than the SV. It is also found that using MSSV models improves the short-term forecasting power.

The sign and direction of the relationship between output growth and uncertainty, which affect the design of economic policies, provide a priori knowledge for understanding the fluctuations in the resources of business cycles and economic activities. In this study, the relationship between output growth and uncertainty is investigated by using the SV model structure in which no suspicious results are obtained because of the assumptions of distribution of errors; better adapts to the data structure than GARCH model structure and allows for the identification of unexpected volatility that is not considered in the GARCH model structure. When parameter forecasts and causalities are examined, it is concluded that there is a mutually positive causality between output growth and output uncertainty. It is determined that, in Turkey, output uncertainty is strongly affected by output growth. In Turkey, which is in developing economies, there is a gap between potential output and actual output. In addition, the reactions, which arise from the policies implemented to close this gap, can have a positive impact on uncertainty. The increase in output uncertainty reduces savings while increasing investments. Since the increase in investment increases output, the output uncertainty positively affects the output.

\section{REFERENCES}

Abel, A. (1983). Optimal investment under uncertainty. American Economic Review, 73, 228- 233.

Aghion, P. and Howitt, P. (2006). "Joseph Schumpeter lecture appropriate growth policy: A unifying Framework."Journal of the European Economic Association, 4(2-3), 269-314.

Bernanke, B. (1983). "Irreversibility, uncertainty, and cyclical investment." Quarterly Journal of Economics, 98, 85-106.

Black, F. (1987). Business Cycles and Equilibrium. Basil Blackwell: New York. Basil

Blackburn, K. (1999). “Can stabilisation policy reduce long-run growth?” The Economic Journal,109, 67-77.

Blackburn, K \& Pelloni, A. (2004). "On the relationship between growth and volatility." Economics Letters, 83, 123-127.

Caballero, R \& Hammour, M. (1994). "The cleansing effect of recessions." American Economic Review, 84, 350-368.

Durbin, J., Koopman, S. J. (1997). "Monte-Carlo maximum likelihood for non-normal state space models." Biometrika, 84, 669- 684.

Friedman, M. (1968). "The role of monetary policy." American Economic Review, 58, 1-17.

Friedman, M. (1977). "Nobel lecture: inflation and unemployment.” Journal of Political Economy, 85(3),451-472.

Gelman, A. \& Rubin B.D. (1992). "Inference from iterative simulation using multiple sequence." Statistical Science, 457-472.

Geweke, J. (2005). Contemporary Bayesian econometrics and statistics (Vol. 537). John Wiley \& Sons. Hamilton, J. D. (1994).Time Series Analysis, Princeton Universities Press, New Jersey.

Keynes, J.M. (1936). The General Theory of Employment, Interest, and Money. Macmillan, London. Kim, S., Neil S., \& Siddhartha C. (1998). "Stochastic volatility: likelihood inference and comparison 
with ARCH models." The Review of Economic Studies, 65(3),361-393.

Koopman, S. J.\& Uspensky, E. H. (2002). "The stochastic volatility in mean model: empirical evidence from international stock markets." Journal of Applied Econometrics, 17, 667 - 689.

Lucas, R.E. (1988). "On the mechanics of economic development. "Journal of Monetary Economics, 22, 3-42.

Lucas, Jr. R.E. (1983), Studies in Business Cycle Theory, The MIT Press.

Mirman, L. (1971). "Uncertainty and optimal consumption decisions." Econometrica, 39, 179-85.

Pindyck, R. (1991). "Irreversibility, uncertainty, and investment." Journal of Economic Literature, 29, 1110-1148.

Sandmo, A. (1970). "The effect of uncertainty on saving decisions." The Review of Economic Studies, 37(3), 353-360.

Schumpeter, J. A. (1939). Business cycle: a theoretical, historical, and statistical analysis of the capitalist process. McGraw-Hill, New York.

Taylor, J. (1979). "Estimation and control of a macroeconomic model with rational expectations." Econometrica, 47, 1267-1286.

Vo, M. T. (2009). "Regime-switching stochastic volatility: Evidence from the crude oil market." Energy Economics, 31(5), 779-788.

Yu, J. (2002). "Forecasting volatility in the New Zealand stock market." Applied Financial Economics, 12(3), 193-202. 